\title{
The preventive cardiovascular effect of a combination of statin and angiotensin receptor blocker at sub-therapeutic doses in middle-aged healthy volunteers
}

Petra Šinigoj1 ${ }^{1}$ Mojca Lunder*2, Martin Šinigoj ${ }^{1}$, Gorazd Drevenšek² and Mišo Šabovič ${ }^{3}$

\author{
Address: ${ }^{1}$ Ultrasound Diagnostics, Medical Center Šinigoj, Kromberk, 5000 Nova Gorica, Slovenia, ${ }^{2}$ Institute of Pharmacology and Experimental \\ Toxicology, Faculty of Medicine, University of Ljubljana, 1000 Ljubljana, Slovenia and ${ }^{3}$ Department of Vascular Disease, University Medical Centre \\ Ljubljana, 1000 Ljubljana, Slovenia \\ Email: Mojca Lunder* - mojca.lunder@mf.uni-lj.si \\ * Corresponding author
}

from I5th Scientific Symposium of the Austrian Pharmacological Society (APHAR) Joint meeting with the Hungarian Society of Experimental and Clinical Pharmacology (MFT) and the Slovenian Pharmacological Society (SDF)

Graz, Austria. 19-21 November 2009

Published: 12 November 2009

BMC Pharmacology 2009, 9(Suppl 2):A63 doi:10.1 186/I47|-2210-9-S2-A63

This abstract is available from: http://www.biomedcentral.com/I47/-22/0/9/S2/A63

(C) 2009 Šinigoj et al; licensee BioMed Central Ltd.

\section{Background}

Endothelial dysfunction is supposed to be a key event in the development of several cardiovascular diseases. In the middle-aged, apparently healthy population, the endothelial function is frequently already impaired, representing the first step in the development of cardiovascular diseases. It seems reasonable to try to improve endothelial dysfunction in the mentioned population also by pharmacological approaches. It can be assumed that therapies that could improve the function of the vascular endothelium would lead to diminishing or slowing the onset of cardiovascular diseases. The aim of our study was to evaluate the protective pleiotropic effects of a combination of statin and angiotensin receptor blocker at sub-therapeutic doses in middle-aged volunteers with low risk for cardiovascular disease on the function of endothelium.

\section{Methods}

Ten healthy volunteers (males) aged from 30 to 50 years without history of cardiovascular disease, diabetes mellitus, hypertension or hypercholesterolemia were recruited for the study. Subjects took a combination of statin (fluvastatin $10 \mathrm{mg}$ ) and angiotensin receptor blocker (valsar$\tan 20 \mathrm{mg}$ ) daily for 30 days. Ultrasound measurements (Aloka Alfa 10 ProSound echo-machine) of flow-medi- ated dilatation (FMD) were repeated three times: at the beginning of the study, after 14 days, and at the end of the study. FMD was measured on the right brachial artery after reactive hyperemia, which was induced by inflation of a pneumatic blood pressure cuff placed around the widest part of the forearm to a systolic pressure of $190 \mathrm{mmHg}$ for 4 minutes. Blood samples were taken at the beginning and at the end of the study in order to make laboratory measurements.

\section{Results}

In almost all subjects involved in or study (9 out of 10) FMD was initially impaired. FMD was significantly improved at the end of the study compared to values at the beginning of the study $(3.98 \pm 0.43 \%$ vs. $5.87 \pm$ $0.72 \% ; \mathrm{p}<0.01)$. The values of diastolic blood pressure were significantly lower at the end of the study $(83.2 \pm 7.4$ $\mathrm{mmHg}$ vs. $71.1 \pm 7.0 \mathrm{mmHg}$; $<0.05)$. The combination of the drugs used in the study did not affect serum cholesterol levels.

\section{Conclusion}

In middle-aged healthy volunteers exposed to a combination of sub-therapeutic doses of fluvastatin and valsartan 
for 30 days, endothelium-dependent vasodilation was significantly improved.

Publish with Bio Med Central and every scientist can read your work free of charge

"BioMed Central will be the most significant development for disseminating the results of biomedical research in our lifetime. " Sir Paul Nurse, Cancer Research UK

Your research papers will be:

- available free of charge to the entire biomedical community

- peer reviewed and published immediately upon acceptance

- cited in PubMed and archived on PubMed Central

- yours - you keep the copyright 